\title{
The Morphological Effects of Asthma, As Well As Conventional and Alternative Asthma Therapies on Parietal and Chief Cells in the Stomach of BALB/c Mice
}

\author{
Los Efectos Morfológicos del Asma, Así Como de las Terapias Convencionales y Alternativas del \\ Asma sobre las Células Parietales y Principales en el Estómago de Ratones BALB/c
}

\author{
"Warren Antonio Vieira; "Hester Magdalena Oberholzer \& *"Etheresia Pretorius
}

VIEIRA, W. A.; OBERHOLZER, H. M. \& PRETORIUS, E. The morphological effects of asthma, as well as conventional and alternative asthma therapies on parietal and chief cells in the stomach of BALB/c mice. Int. J. Morphol., 29(4):1341-1350, 2011.

SUMMARY: Scientific literature, although limited in this area, supports the hypothesis that asthma, by means of selective leukocyte trafficking between the various mucosal and glandular sites of the body, can have the same pathophysiological effects on the stomach as the airways. This study aimed to determine if asthma, in the absence and presence of various asthma therapies (Hydrocortisone and Modul $8^{\mathrm{TM}}$ ), imparted any morphological alteration on the stomach parietal and chief cells. The BALB/c murine asthmatic mouse model was the model of choice in this study. The asthma induction protocol as well as the asthma therapies were proved to be effective with the aid of bronchial lavage fluid leukocyte quantification. Fundic and pyloric biopsies were extracted at termination and assessed by means of transmission electron, scanning electron and light microscopy. The extracted fundic and pyloric biopsies revealed asthma alone induced parietal cell hypertrophy (increase in parietal cell size $\mathrm{P}<0.000100$ in both stomach regions) and chief cell hyper functioning. The use of Hydrocortisone and Modul $8^{\mathrm{TM}}$, as a therapy to correct the perceived gastric alterations were dismal; only in the case of fundic parietal cells were both treatments able to compensate for the hypertrophic effect caused by asthma, while in the pylorus parietal cell asthma- induced hypertrophy was only compensated for by Modul $8^{\mathrm{TM}}$.

KEY WORDS: Fundus; Pylorus; Hypertrophy; Hypersecretion; TEM.

\section{INTRODUCTION}

Asthma is a well-known disease of the lungs, and although it affects other organs and systems, little research has focused on its effects on the gastrointestinal tract (GIT). The GIT plays an important role in the immune functioning, and due to continual exposure to antigens. The gut-associated lymphoid tissue (GALT) of the stomach, like that of the rest of the GIT, is essential in preventing harmful antigen uptake while still allowing the absorption of nutrient molecules (Awang-Hazmi et al., 2007). The GALT of the stomach is composed of numerous components including diffuse lymphatic tissues, intraepithelial lymphocytes, epithelium and eosinophils.

Selective trafficking of various leukocytes between the various glandular and mucosal sites, known to occur in animals but largely unstudied in the case of humans, is hypothesized to allow bronchial asthma the ability to indu- ce the same pathophysiological effects on the stomach as the respiratory tissues (Wallaert et al., 1995; Bernsand et al., 2003; Rudzik et al., 1975; Nepomnyashchikh et al., 2004; Nauta et al., 2008).

A defining histopathological feature of the respiratory tissues amongst asthmatics is the increased infiltration of leukocytes, predominantly eosinophils and allergen-specific CD4+ Th2 cells (Nauta et al.; Warner \& Knight, 2008; Kay, 1988; Sumi \& Hamid, 2007; Lloyd \& Rankin, 2003; D'Ambrosio et al., 2003; Gwinn et al., 2006; Kelly et al., 2007). The entire stomach mucosa during asthma, as in the respiratory tissues, has been noted to show an increased influx of lymphocytes; however, no studies to date have determined if these invading lymphocytes are allergen-specific CD4+ Th2 cells (Nepomnyashchikh et al.).

\footnotetext{
* Department of Anatomy, Faculty of Health Sciences, University of Pretoria, South Africa.

** Department of Physiology, Faculty of Health Sciences, University of Pretoria, South Africa.
} 
As enhanced leukocyte infiltration into a vascularized tissue is a common feature of inflammation, the stomach of asthmatic patients may be in a state of inflammation (Kay; Rang et al., 2003).

Goblet cell hyperplasia and increased mucus production is commonly described within the airways of asthmatics along with an alteration in the composition of the released mucus (Rogers, 2002; Fahy, 2002; Mauad et al., 2007). Under asthmatic conditions, mucin protein expression appears to be altered, with the mucus itself being found to be more adhesive and less fluid in nature (Fahy; Gordon; Mauad et al.; Sumi \& Hamid; Warner \& Knight). Literature suggests a mucin expression alteration within the fundus of asthmatics as well.

The fundal surface epithelium mucin granules have been seen to possess a polymorphic nature based on the severity of the individual's asthma. Severe to moderate asthmatics possess mucin granules with an electron transparent nature when viewed with a transmission electron microscope (TEM) while mild to moderate asthmatics mucin granules possess a osmophilic nature (Nepomnyashchikh et al.). Moderate to severe asthmatics hold a large number of mixt-cells, in possession of a large number of mucin granules, within their fundal glands. The occurrence of these mixt-cells may either be the result of delayed glandular differentiation or due to the inhibition of protein synthesis due to stomach degeneration and emergency compensation through increased mucus production (Nepomnyashchikh et al.). In the pylorus, on the other hand, surface epithelium cells possess round, electron dense granules within moderate asthmatics, while its endocrine cells undergo hyperplasia (Nepomnyashchikh et al.).

From the above assessment of literature, the assessment of the effect of asthma on the stomach has not been carried out in great detail. Much detail still needs to be gathered as to the reason for the perceived phenomena as well as determining if the perceived alterations are indeed a result of bronchial asthma.

This study therefore aims to explore the morphological interactions of asthma on the stomach parietal and chief cells, through the use of the clinically relevant $\mathrm{BALB} / \mathrm{c}$ asthmatic murine model. Furthermore, this study aimed to determine, if any, the effects which various asthma therapies (Hydrocortisone, a conventional asthma therapy, and Modul $8^{\mathrm{TM}}$ (Manufacturer: Natel Neutratec SA (Pty) Ltd; Johannesburg, South Africa), a homeopathic immunomodulator employed as an asthma remedy) had in this situation.

\section{MATERIAL AND METHOD}

Implementing the asthmatic BALB/c mouse animal model. Six-week-old (female) BALB/c mice (each of average weight $20 \mathrm{~g}$ ) were maintained in the University of Pretoria Biomedical Research Centre and provided Ovalbumin (OVA)-free food and water ad libitum, All experimental protocols complied with the requirements and standards of the University of Pretoria's Animal Use and Care Committee and the WHO/UNESCO. The ethical clearance number for this study is 151/2006. Lab Animal Technologists monitored the animals every day for clinical signs or behavioral abnormalities, of which none were observed.

Mice were divided into the following experimental groups: six control animals, six asthmatic animals receiving no treatment, six asthmatic animals treated with physiological comparable levels of Hydrocortisone (100mg/ $\mathrm{kg}$ ) and six asthmatic animals treated with the homeopathic product Modul8 ${ }^{\mathrm{TM}}$ (10\%). Implementation of the BALB/c asthmatic mouse model involved sensitization, nebulization and treatment of animals on specific days as indicated in Table I.

Sensitization of the animals involved the intraperitoneal injection of $25 \mathrm{mg}$ ovalbumin (OVA) (Grade $\mathrm{V}$; Sigma Aldrich) and $2 \mathrm{mg} \mathrm{Al}(\mathrm{OH})_{3}$ dissolved in $0.5 \mathrm{ml}$ of $0.9 \%$ saline solution. All animals in the asthmatic and two treatment groups were sensitized.

Nebulization of the animals with $1 \%$ OVA in PBS was done using an inhalation exposure system (IES) (GlasCOL $®$ Inhalation Exposure System, Model 099C A4212, Terre Haute, Indiana). Standard protocol was applied for the IES. Nebulization involved placing the six animals from the same experimental group inside a stainless steel wire mesh basket, which is divided into five equal compartments. Each compartment therefore held the six animals from the same experimental group. One complete cycle in the IES included a preheat cycle of 15 minutes followed by the nebulization with the OVA for 60 minutes, a cloud decay cycle for 15 minutes and a decontamination cycle also 15 minutes as per standard protocol. Mice were nebulized twice daily.

Treatment procedures involved in this study were conducted by veterinary technicians. This involved the administration of Modul ${ }^{\mathrm{TM}}$ and hydrocortisone to the asthmatic animals. Solu-Cortef ${ }^{\mathrm{TM}}$ 100mg Hydrocortisone (Pfizer Laboratories (Pty) Limited), dissolved in sterile PBS was injected intra-peritoneally, while Modul $8^{\mathrm{TM}}$ (Natel Healthcare SA (PTY) Ltd.) was administered orally on the 
VIEIRA, W. A.; OBERHOLZER, H. M. \& PRETORIUS, E. The morphological effects of asthma, as well as conventional and alternative asthma therapies on parietal and chief cells in the stomach of BALB/c mice. Int. J. Morphol., 29(4):1341-1350, 2011.

Table I. Implementation of the BALB/c asthmatic mouse model

\begin{tabular}{lc}
\hline $\begin{array}{l}\text { Steps for Implementation and } \\
\text { Treatment }\end{array}$ & Days \\
\hline Sensitization & 0,5 \\
Nebulization & $13,14,15,30,31,32$ \\
Treatment & $15-18,22-25,36-39$ \\
Termination & 42 \\
\hline
\end{tabular}

specific treatment days as indicated in Table I. Modul8 ${ }^{\mathrm{TM}}$ is a complex homeopathic immunomodulator that enhances the immunity of an individual and consists of a mixture of different substances in different concentrations. The following substances are found in this product: Aconitum napellus (D20), Arsenicum album (D18), Asafoetida (D20), Calcarea carbonica (D16), Conium maculatum (DH17), Ipecacuanha (D13), Phosphorus (D20), Rhus toxicodendron (D17), silicea (D20), sulfur (D24), Thuja occidentalis (D19), alcohol $(0.2 \%, \mathrm{v} / \mathrm{v})$ and purified water $(44.050 \mathrm{ml})$. The product is available in $50 \mathrm{ml}$ bottles on which the declared potencies (D) are expressed. The latter is an indication of an index of 10-fold dilution. The dosage of Modul8 ${ }^{\mathrm{TM}}$ was calculated from the adult human dosage and a dosage of $28 \mathrm{ml} / \mathrm{kg}$ was administered once daily via oral gavage as it allows for administration of a controlled amount of compound. The adult dosage of $100 \mathrm{mg} / \mathrm{kg}$ body weight hydrocortisone was converted to the average mass of a mouse, which was taken at $20 \mathrm{~g}$. The hydrocortisone was administered via intraperitoneal injection, as was indicated on the product itself and since it is one of the most common routes of administration in mice.

BAL technique. On the day of termination, a small skin incision was made in the skin of each mouse in the ventral region of the trachea. This was followed by blunt dissection to expose the trachea. A small transverse incision was made below the larynx through which a $21 \mathrm{G}$ venous catheter was employed to inject $0.3 \mathrm{ml}$ of saline into the trachea and aspirated with a syringe. The BAL fluid was collected and pooled for the individual groups. The samples were then centrifuged for two minutes at 1000rpm and used to prepare histological smears. The smears were stained with Rapid Hematological Stain and viewed with a Nikon Optiphot light microscope. A hundred cells were counted per slide and statistically analyzed.

Tissue for TEM. Biopsies from the pylorus and fundus were fixed in a $2.5 \%$ glutaraldehyde/formaldehyde solution immediately after extraction, for one hour, and subsequently rinsed with $0.075 \mathrm{M}$ phosphate buffer solution (PBS) three times for 15 minutes. The biopsies were exposed to the secondary fixative, $0.5 \%$ osmium tetroxide, for one hour after which the biopsies were rinsed with $0.075 \mathrm{M}$ PBS once again for three times for 15 minutes. The biopsies were then dehydrated in $30 \%, 50 \%, 70 \%, 90 \%$ and three changes of absolute ethanol. The biopsies were embedded in quetol resin, from which ultra-thin sections were cut using a diamond knife and contrasted with uranyl acetate and lead citrate. The contrasted TEM sections were analyzed with a JOEL JEM 2100F transmission electron microscope.

Tissue for light microscopy. Biopsies from the pylorus and fundus were fixed in a $2.5 \%$ glutaraldehyde/formaldehyde solution immediately after extraction, for one hour, and subsequently rinsed with $0.075 \mathrm{M}$ PBS three times for 15 minutes. The biopsies were then dehydrated in $30 \%, 50 \%$, $70 \%, 90 \%$ and three changes of absolute ethanol. The biopsies were embedded in LR white resin and sectioned at a thickness of $1 \mathrm{~mm}$ and stained with Toluidine Blue $\mathrm{O}$ solution. The biopsies were analyzed with a Nikon Optiphot light microscope.

Statistical analysis of data. The statistical comparisons were conducted using the statistical program NCSS $®$ at a significance level of 0.05 .

BAL fluid leukocyte counts. Three stained BAL fluid smears were chosen at random, for each experimental group, for leukocyte differentiation and quantification. A hundred cells were quantified per slide at a 100x magnification. Each leukocyte species (basophil, eosinophil, lymphocyte, monocyte and neutrophil) was considered separately between the four experimental groups via one-way ANOVA's with Tukey-Kramer Multiple-Comparison Tests used for pos-hoc comparisons. For each experimental group the average differential BAL fluid leukocyte numbers and their associated standard deviations were calculated.

Parietal cell size. 90 random parietal cells were measured, based on the principles of Feret's minimal diameter, of three random mice from each experimental group, within both the fundus and pylorus with the aid of Olympus Soft Imaging Solutions ${ }^{\circledR}$ software. The data was utilized for statistical assessment of these cells sizes:

Between the four experimental groups by means of a Kruskal-Wallis one-way ANOVA, in each region of the stomach, due to a lack of normality in the data's distribution. The Tukey-Kramer Multiple-Comparison Test was utilized for pos-hoc comparisons to determine where significance lay.

Between the two regions of the stomach within each experimental group by means of the Mann-Whitney U test, due to the lack of normality in the data's distribution. The null hypothesis for the control, asthma and Modul $8^{\mathrm{TM}}$ tests 
was that the fundic parietal cells, which appeared bigger to the eye then those of the pylorus, were significantly larger than that resident in the pylorus. The null hypothesis for the Hydrocortisone test was that the pyloric parietal cells, which appeared bigger to the eye then those of the fundus, were larger than those resident in the fundus.

Feret's minimum diameter is a measuring method utilized to estimate the length or size of a cell or fiber (Briguet et al., 2004; Alamar et al., 2008). It is the minimum distance between two parallel tangents at opposite sides of the cell or fibers borders (Briguet et al.). This measuring method has the advantage of being insensitive to deviations from optimal cross-sectioning while still being reliable to quantify detectable size differences (Briguet et al.).

\section{RESULTS AND DISCUSSION}

When comparing the different pathophysiological features of the lungs and the stomach, great similarity is seen. Table II expresses the over lapping pathophysiological features found to occur within the stomach and lungs and airways of human asthmatics, while Table III expresses all the currently known pathological features associated with the stomach in asthmatics.

Due to the information shown in Tables II and III, in the current manuscript, a detailed ultrastructural investigation of the stomach cells (pariental and chief cells) was performed. Also, we compared the BAL fluid leukocyte counts between the different groups, in order to confirm asthma.

The averaged differential BAL fluid leukocyte counts of this study, for each experimental group at termination, were presented in Figure 1. From Figure 1 it can be seen that the eosinophil levels increased significantly amongst the untreated asthmatic mice in comparison to the nonasthmatic control mice $(\mathrm{P}=0.00312)$, while both treatment groups showed eosinophil levels which were statistically indifferent from control levels but significantly lower than that of the untreated asthmatic mice. The untreated asthmatic mice of this study showed a five-fold increase in eosinophil number, a clear indication that asthma was indeed induced amongst these mice. The collected BAL results for this study were theoretically expected as untreated asthmatics have been reported to show an increase in BAL fluid eosinophil levels while the use of corticosteroids, such as Hydrocortisone, have been shown to reduce the infiltration of eosinophils amongst asthmatics (Gwinn et al.; Holgate, 2008; Venge, 1988).

Hydrocortisone is one of the prominent treatments used in the battle against asthma due to its highly effective anti-inflammatory and immunosuppressive effects (Warner \& Knight; Rang et al.; Garrod, 1958; Crompton, 2006). Unfortunately, due to it this therapy's associated detrimental effects on the body, other therapy options are sought after in the fight against asthma - one such option being the use of homeopathic immunomodulators. Modul8 ${ }^{\mathrm{TM}}$ is a highly diluted, non-toxic homeopathic remedy which has been suggested for use by patients who experience diseases where their immune system is compromised, such as asthma, due to its ability to modulate the immune system naturally (Modul8 Inc., 2009).

Parietal cell alterations. Morphological assessment of the gastric mucosa's parietal cells, situated within the fundus and pylorus at both low magnification (light microscopy) and high magnification (TEM), showed no appreciable differences between the four experimental groups, Figures 2 (light microscopy) and 3 (TEM) reveal the morphology at low and high magnification respectively of the different experimental groups pylorus parietal cells.

Table II. The overlapping morphological features, ascribed to asthma, within the lungs and airways and the stomach of man.

\begin{tabular}{|c|c|c|}
\hline Morphological phenomena ascribed to asthma & Lungs \& Airways & Stomach \\
\hline Cellular atrophy & $\begin{array}{c}\square \\
\text { Surf ace epithelium }\end{array}$ & $\begin{array}{c}\square \\
\begin{array}{c}\text { Surface, pit, crypt and glandular } \\
\text { epithelium }\end{array}\end{array}$ \\
\hline Increased leukocyte infiltration & $\begin{array}{c}\square \\
\text { Eosinophils, lymphocytes, mast cells, } \\
\text { monocytes/macrophages and neutrophils }\end{array}$ & $\begin{array}{c}\square \\
\text { Lymphocytes }\end{array}$ \\
\hline Mucus composition alterations & $\begin{array}{c}\square \\
\text { Goblet cells }\end{array}$ & $\begin{array}{c}\square \\
\text { Fundic surface epithelium }\end{array}$ \\
\hline
\end{tabular}

Symbol: $\square=$ feature present. 
Table III. The currently known pathological features, ascribed to asthma, within the stomach of man.

\section{Morphological phenomena ascribed to asthma}

Altered mucin granule composition and/or size in both the fundus and pylorus
Cellular atrophy
Increased leukocyte (lymphocyte) infiltration
Parietal cell hyperplasia and hyperfunctioning
The gastric folds microcirculatory beds endothelium takes on a heterogeneous nature

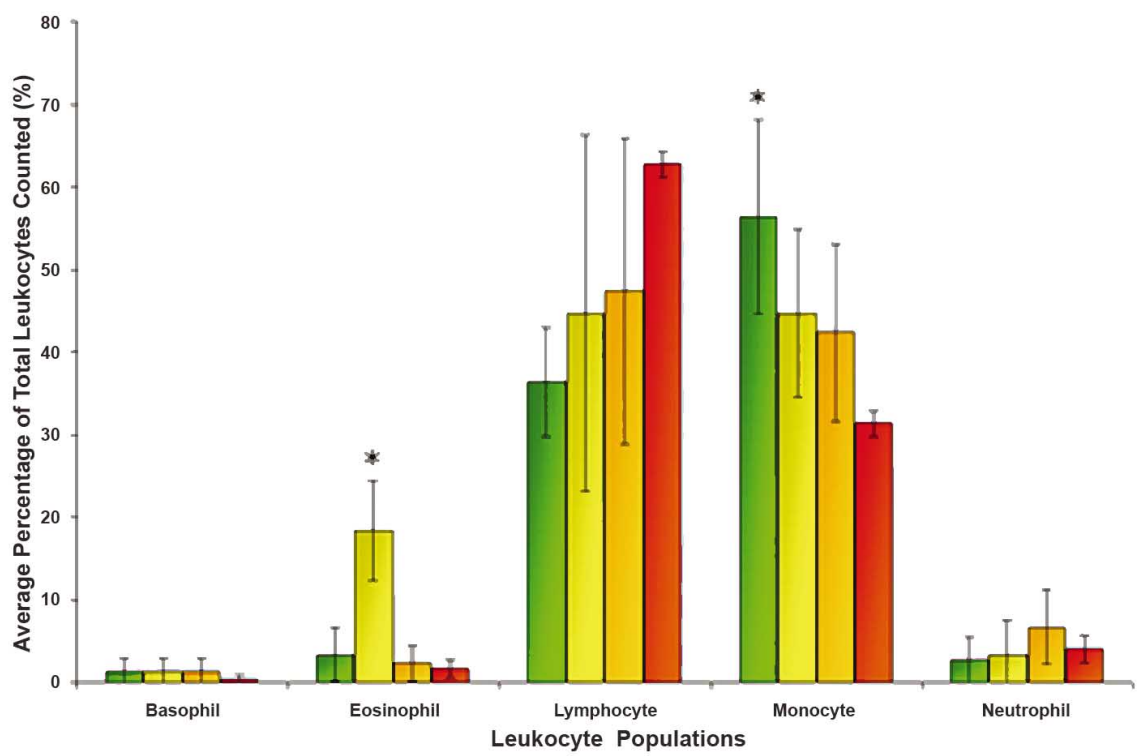

Fig. 1. White blood cells quantified from BAL fluid smears derived from experimental BALB/c mice groups. represents the non-asthmatic control group; represents the untreated asthmatic group; represents the Modul8 ${ }^{\mathrm{TM}}$ treated asthmatic group $\square$ represents the cortisone treated group. Y-error bars represent standard deviation. * indicates significance at a level of 0.05 .

An important difference between the four experimental groups was that of cell size, as depicted graphically in Figure 4. Statistical assessment of Feret's minimum diameter for the studied BALB/c mice's fundic and pyloric parietal cells revealed that hypertrophy was induced under untreated asthmatic conditions while in the fundus both conventional and homeopathic therapies were able to counteract this size increase and restore the parietal cells back to control sizes while only Modul $8^{\mathrm{TM}}$ was able to counteract the asthma induced size increase in the pylorus $(\mathrm{P}<0.0000100$ for both analyses). The pyloric parietal cells showed a significantly greater degree of size increase under hydrocortisone treated asthmatic conditions in relation to untreated asthmatic conditions. This clearly indicates the ability of hydrocortisones to induce pyloric parietal cell hypertrophy.

In literature, hypertrophy amongst the parietal cells of asthmatics is not a documented feature, hence this feature may not be prominent amongst human asthmatics, the main species of study in literature so far in relation to asthma and the GIT, or it may simply be undocumented. Gastrin could be a possible mediator of this gastric effect as it has been shown, at elevated levels, to give rise to gastric mucosa hypertrophy as seen in Zollinger-Ellison syndrome (Burkitt et al., 2009; Nakajima, 2002). The occurrence of human parietal cell hyperplasia has already been linked to gastrin and thus gastrin could be a possible means by which the perceived hypertrophy in this study was observed, although further studies that quantify the circulating and gastric mucosa levels of this peptide under asthmatic conditions would need to be conducted (Rudzik et al.). Alternatively, the mechanism by which asthma would induce parietal cell hypertrophy may possibly involve the diseases immune stimulation as Modul $8^{\mathrm{TM}}$, an immunomodulator, was able to restore the stomach's parietal cell populations back to control sizes.

Comparison of parietal cell size between the fundus and pylorus revealed that those resident within the fundus were significantly larger in size than their pyloric counter parts in all cases except amongst the hydrocortisone treated mice (control $\mathrm{P}<0.0000100 ;$ asthma $\mathrm{P}=$ 0.0000600 and Modul8 ${ }^{\mathrm{TM}} \mathrm{P}=$ 0.0366 ). Amongst the hydrocortisone treated mice the parietal cells resident within the pylorus were significantly larger in size then their fundic counter parts $(P=0.0000310)$. As the fundic parietal cells were larger than those of the pylorus, under control and untreated asthmatic conditions, the significant increase in pyloric parietal cell size under hydrocortisone treated conditions clearly highlights a so far undescribed area in the specific effect of hydrocortisone on stomach parietal cells. The reason(s) for this effect is unknown.

Chief cell alterations. Morphological assessment of the gastric mucosa's chief cells, situated within the fundus and pylorus at low (light microscopy) 

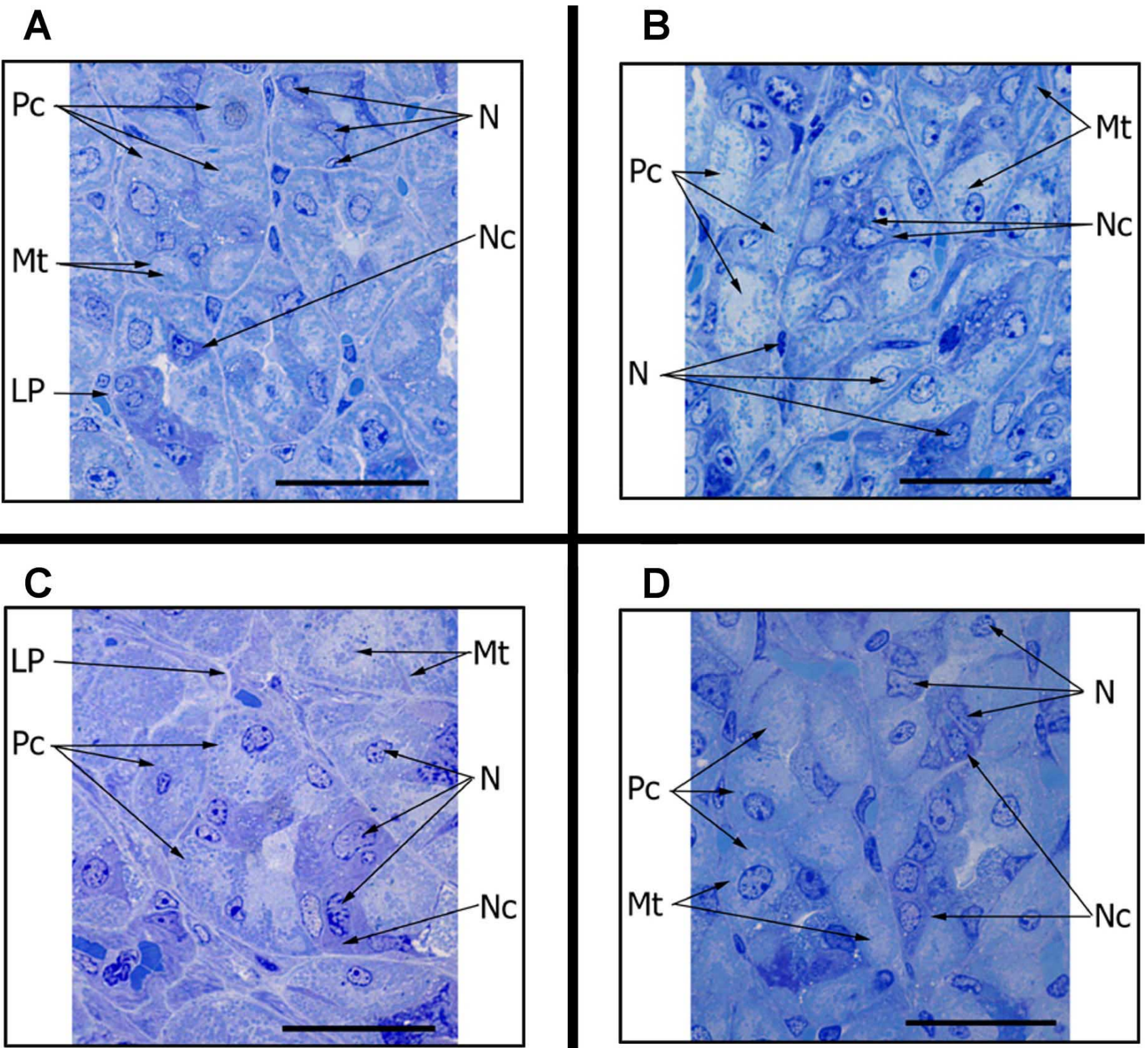

Fig. 2. Light microscopic images of a longitudinal section of pyloric parietal cells, taken at 40x magnification, derived from the stomach of (A) a non-asthmatic control mouse, (B) an untreated asthmatic mouse, (C) a Hydrocortisone treated asthmatic mouse and (D) a Modul $8^{\mathrm{TM}}$ treated asthmatic mouse. The black line represents a scale bar of 50mm. Ca - Canaliculi, Pc - Parietal cells, LP - Lamina propria, PM - Plasma Membrane, Mt - Mitochondria, RER - Rough Endoplasmic Reticulum, N - Nucleus, Zc - Zymogenic cells, Nc Neck cells, Zg - Zymogen granules.

and high (TEM) magnification, showed asthma as well as the employed treatments for the disease to have a significant impact on these cells secretory functions. Figure 5 reveals the morphology at low magnification of stomach fundic and pylorus chief cells, while Figure 6 reveals the morphology of the stomach pylorus chief cells at high magnification for the different experimental groups.

Under control conditions, the BALB/c mice held a relatively large amount of zymogenic granules within their fundic and pyloric chief cells, clearly identifiable due to their staining with Toluidine Blue O solution. This is in line with theory as gastric chief cells not only secrete pepsin in response to neuronal and hormonal stimuli but also secrete a large basal amount of pepsinogen (Tani et al., 1989). This base line secretion was noted to be greater in the pylorus than in the fundus of the control mice, as can be seen in Figure 5. Under untreated asthmatic conditions there was an increase in the amount of zymogenic granules present within the gastric mucosa's chief cells in comparison to the 


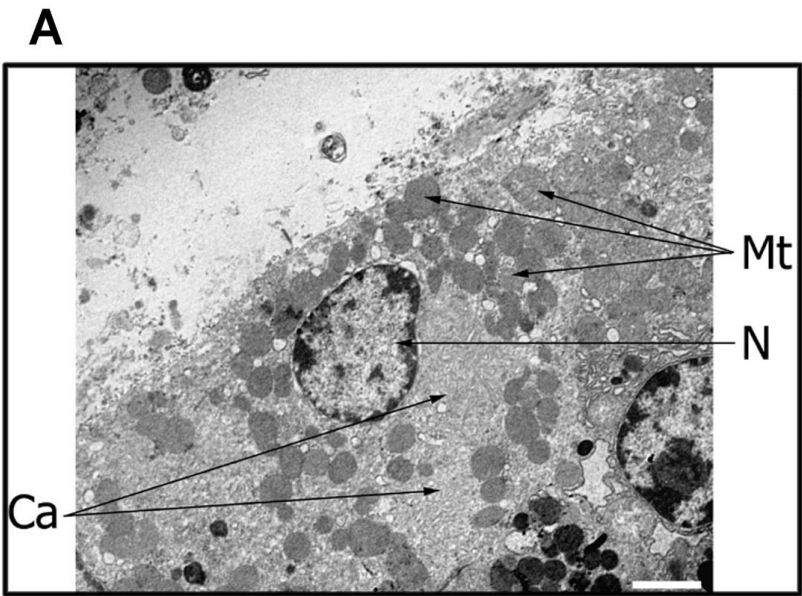

B
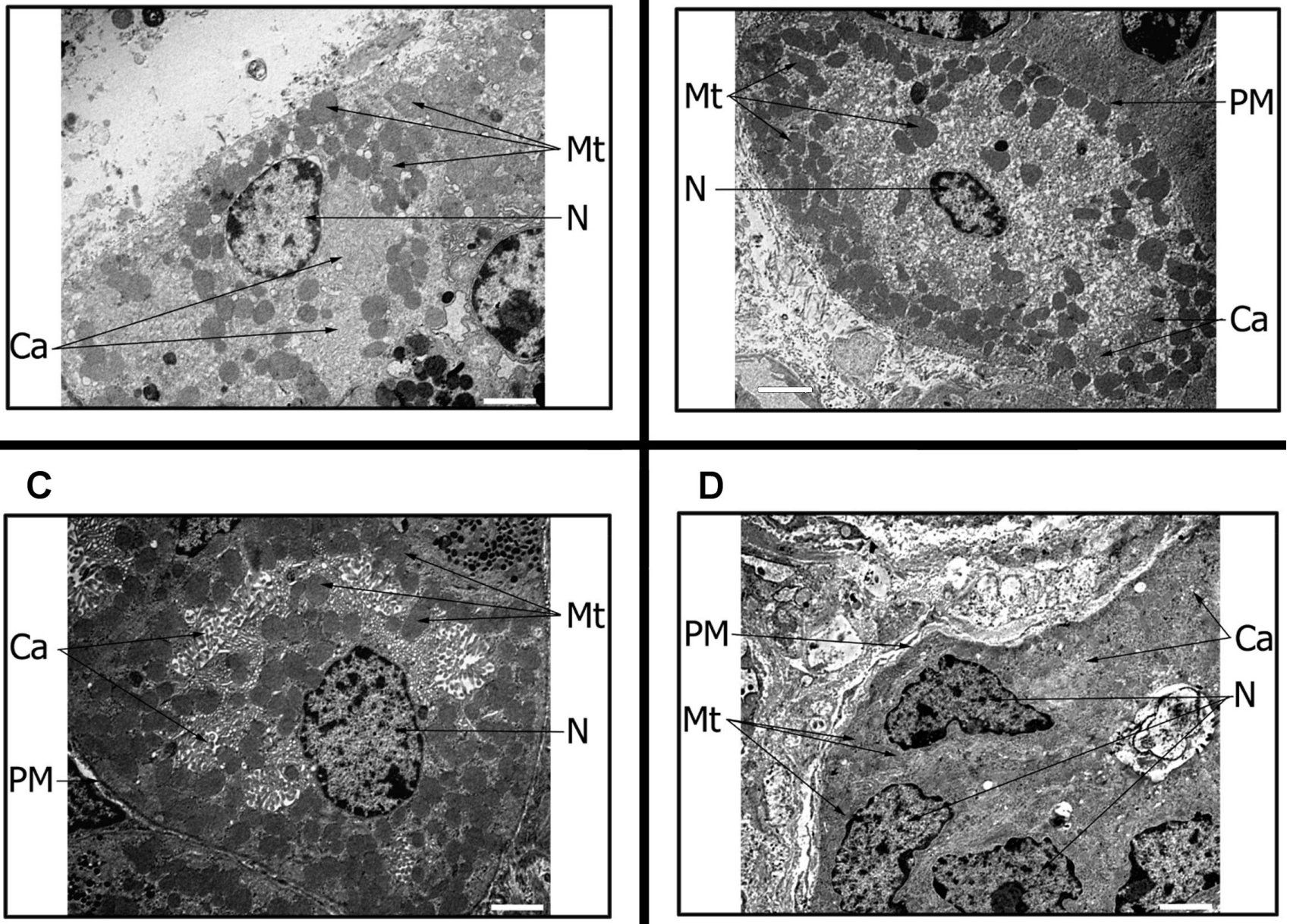

\section{D}

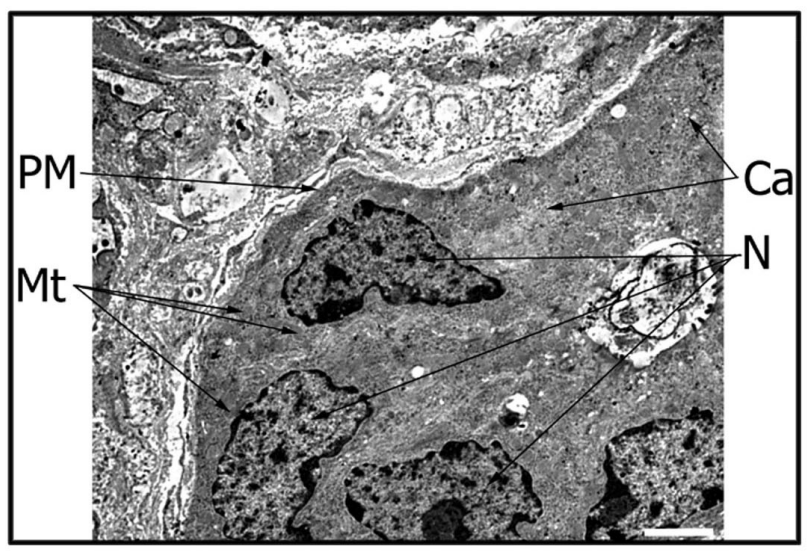

Fig. 3. Transmission electron microscopic images of a longitudinal section of pyloric parietal cells derived from the stomach of (A) a non-asthmatic control mouse, (B) an untreated asthmatic mouse, (C) a Hydrocortisone treated asthmatic mouse and (D) a Modul $8^{\mathrm{TM}}$ treated asthmatic mouse. The white scale bars represent $2 \mu \mathrm{m}$. Ca - Canaliculi, Pc - Parietal cells, LP - Lamina propria, PM - Plasma Membrane, Mt - Mitochondria, RER - Rough Endoplasmic Reticulum, N - Nucleus, Zc - Zymogenic cells, Nc - Neck cells, Zg Zymogen granules.

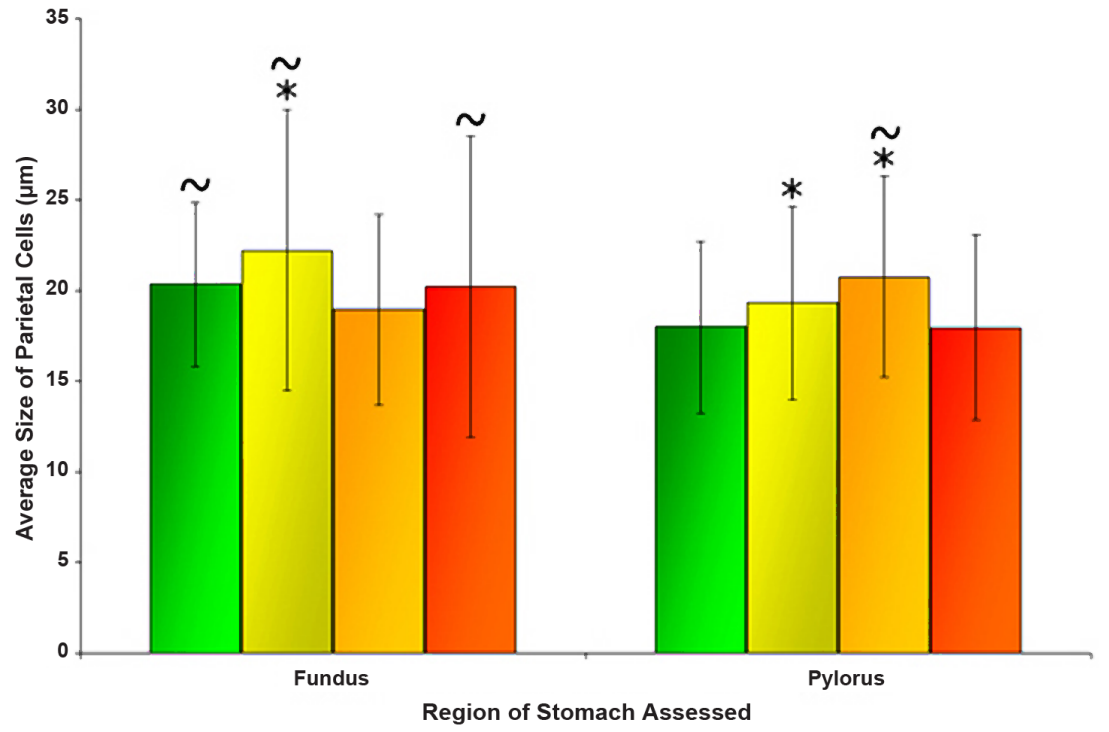

Fig. 4. Average parietal cell size within the fundus and pylorus of the stomach of each experimental group. represents the nonasthmatic control group; represents the untreated asthmatic group; represents the hydrocortisone treatment asthmatic group; represents the Modul8 ${ }^{\mathrm{TM}}$ treatment asthmatic group. Y-error bars represent standard deviation; * indicates significance for between group comparison, for each stomach region, at a level of 0.05 and $\sim$ indicates significance for region comparison of the stomach, within each group, at a level of 0.05 . 


\section{F undus $\quad$ Pylorus}

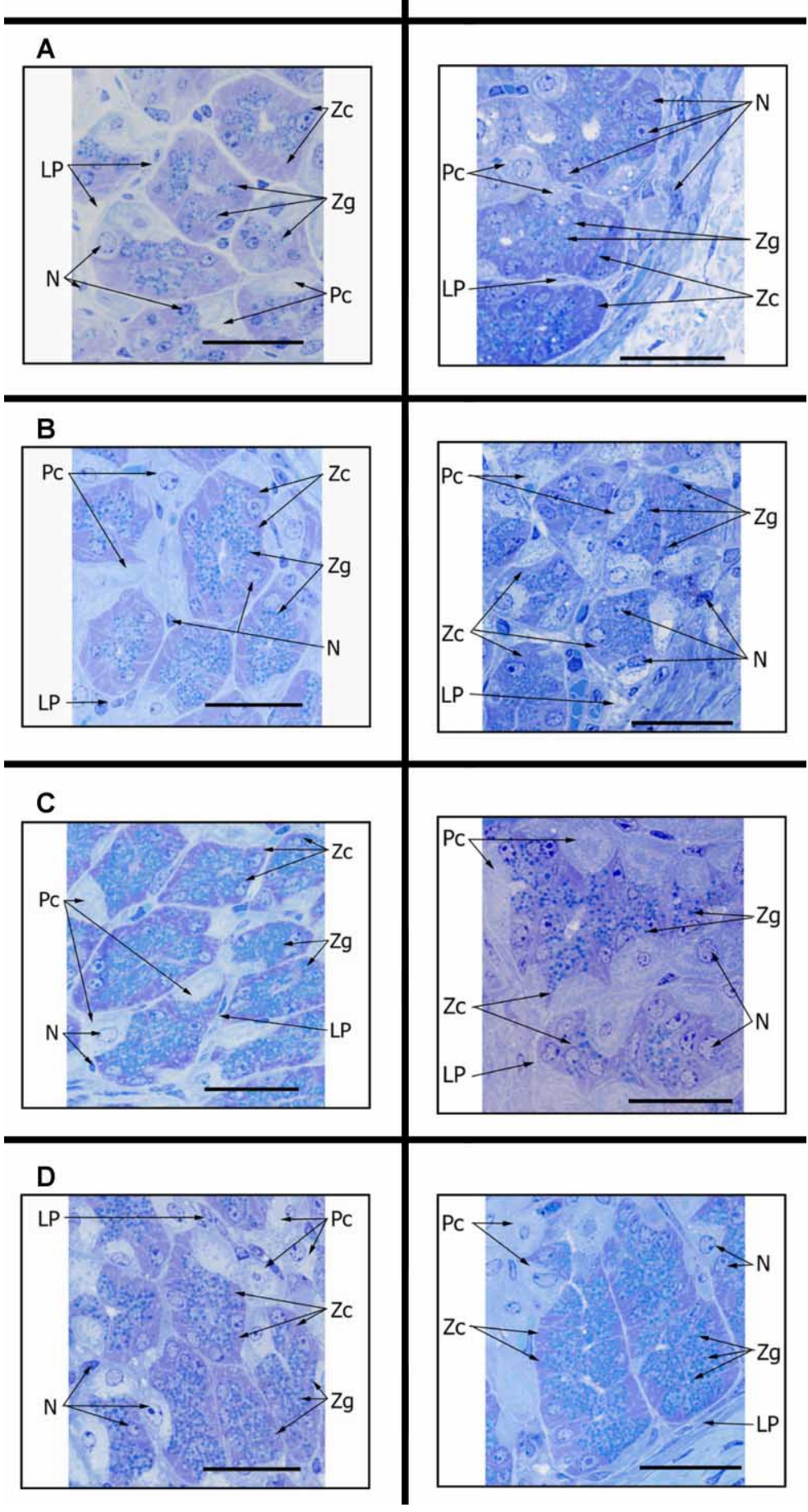

Fig. 5. Light microscopic images of a longitudinal section, at various magnifications, of the fundic and pyloric chief cells, taken at 40x magnification, derived from the stomach of a (A) a non-asthmatic control mouse, (B) a untreated asthmatic mouse, (C) a Hydrocortisone treated asthmatic mouse and (D) a Modul $8^{\mathrm{TM}}$ treated asthmatic mouse. The black line represents a scale bar of $50 \mathrm{~mm}$. their respective control situations. The increase was noted to be greater within the fundic chief cells. Such alterations have not been documented before in the literature.

Research, with the aid of canine and rodent models, has shown that histamine is able to induce a species specific secretion of pepsinogen by the gastric chief cells (Wiederanders et al., 1960; Lopez-Diaz et al., 2006; Tani \& Tanaka, 1990). In the case of rat chief cells, Lopez-Diaz et al. have shown that histamine, possibly working through the chief cells $\mathrm{H} 2$ receptors, induces a dose-dependent pepsinogen secretion. It is known that under an allergic response, such as in the case of asthma, the body releases a large amount of histamine which might be the cause of the perceived increase in gastric chief cell secretory activity within the experimental model, if the BALB/c mice chief cells respond as rats chief cells to increased histamine levels (Nelson \& Cox, 2005).

Hydrocortisone and Modul8 ${ }^{\mathrm{TM}}$ induced even greater increases in the amount of zymogenic granules present within the asthmatic mice chief cells in relation to the control situation and untreated asthmatic situation, as expressed in Figure 5. In the case of Hydrocortisone this increase in zymogenic granule production, above that induced by the disease alone, is understandable and expected, as research has documented that corticosteroids are able to induce the hypersecretion of pepsinogen from these cells (Wiederanders $e t$ al.). Hydrocortisone also appears to have a site specific affect on the gastric mucosa, increasing the number and size of the zymogenic granules in the fundic chief cells more severely than the corresponding pyloric cells. The reason for Modul $8^{\mathrm{TM}}$ inducing such an effect on zymogenic granule secretion is unknown nor is it known whether it functions by a similar mechanism to Hydrocortisone, in this respect, but it also appears to have a site specific affect on the gastric mucosa, increasing the number and size of the zymogenic granules in the pylorus chief cells more severely than the corresponding fundic cells. Modul $8^{\mathrm{TM}}$ and hydrocortisone can be seen to both be ineffective treatments in compensating in the asthma, instead induced hyperfunctioning of gastric chief cells is observed. 


\section{CONCLUSION}

Asthma does appear to significantly affect the morphology of the stomachs parietal and chief cells - parietal cell hypertrophy and chief cell hyperfunctioning - although these features have not been documented thus far in literature. This may be due to the alterations noted being a species specific phenotypic expression of the disease, due the specific protocol utilized events or simply not assessed thus far in humans.

The beneficial effects of using Hydrocortisone and Modul $8^{\mathrm{TM}}$ as a therapy to correct the perceived gastric alterations are not very strong as both were found to aggravate the situation more often than help. Hydrocortisone was associated with aggravation of asthmatic induced pyloric parietal cell hypertrophy and fundic and pyloric chief cell hyperfunctioning. Modul ${ }^{\mathrm{TM}}$ was associated with the aggravation of asthma induced pyloric and fundic chief cell hyperfunctioning. This study also provides evidence that Hydrocortisone, and even Modul $8^{\mathrm{TM}}$, may have area specific effects on the cells which reside within the gastric mucosa. Hydrocortisone appears to have a more detrimental effect on the pyloric parietal cells and fundic chief cells, while Modul $8^{\mathrm{TM}}$ appears to have a greater detrimental effect on the pyloric chief cells. The aspect of area specific effects of Hydrocortisone has apparently not been considered in literature thus far, and would be an important avenue of research in trying to solve some of the controversy surrounding Hydrocortisone and its detrimental effects on the gastric mucosa. The effects of Modul $8^{\mathrm{TM}}$ on the stomach have not been assessed in scientific literature. Modul $8^{\mathrm{TM}}$ did show some benefits as it was able to restore both the pyloric and fundic parietal cells back to control sizes under asthmatic conditions. Thus Modul $8^{\mathrm{TM}}$ may provide a useful alternative, as complementary medicine, to more traditional treatment regimes but further studies would need to be performed in order to determine if this is the case, and how to circumvent the chief cell aggravation it appears to induce.

VIEIRA, W. A.; OBERHOLZER, H. M. \& PRETORIUS, E. Los efectos morfológicos del asma, así como de las terapias convencionales y alternativas del asma sobre las células parietales y principales en el estómago de ratones BALB/c. Int. J. Morphol., 29(4):1341$1350,2011$.

RESUMEN: La literatura científica, aunque limitada en esta área, apoya la hipótesis de que el asma, por medio del tráfico selectivo de leucocitos entre los diferentes sitios y la mucosa glandular del cuerpo, puede tener los mismos efectos fisiopatológicos en el estómago y las vías respiratorias. Este estudio tuvo como objetivo determinar si el asma, en ausencia y presencia de diversos tratamientos para el asma (hidrocortisona y Modul $8^{\mathrm{TM}}$ ), generó alguna alteración morfológica en las céluals parietales y principales del estómago. El modelo murino BALB/c del ratón asmático fue el modelo de elección en este estudio. El protocolo de inducción de asma, así como el tratamiento del asma demostró ser eficaz con la ayuda de lavado bronquial y cuantificación leucocitaria del fluido. Biopsias de las regiones fúndica y pilórica fueron extraídas y evaluadas por medio de microscopía electrónica de transmisión, de barrido y de luz. Las biopsias extraídas de la región fúndica y pilórica revelaron que el asma solamente induce hipertrofia de las células parietales (aumento del tamaño de las células parietales $\mathrm{P}<0,00001$ en ambas regiones del estómago) e hiperfuncionamiento de las células principales. El uso de hidrocortisona y Modul8 ${ }^{\mathrm{TM}}$, como una terapia para corregir las alteraciones gástricas fue disimil, sólo en el caso de las células parietales fúndicas ambos tratamientos fueron capaces de compensar el efecto hipertrófico causado por el asma, mientras que en la célula parietal pílorica la hipertrofia inducida por el asma solamente se vio compensada por Modul $8^{\mathrm{TM}}$.

PALABRAS CLAVE: Fondo; Píloro; Hipertrofia; Hipersecreción; TEM.

\section{REFERENCES}

Alamar, M. C.; Vanstreels, E; Oey, M. L; Molt?, E. \& Nicola?, B. M. Micromechanical behaviour of apple tissue in tensile and compression tests: Storage conditions and cultivar effect. $J$. Food Eng., 86(3):324-33, 2008.

Awang-Hazmi, A. J.; Zuki, A. B. Z.; Zamri-Saas, M. \& Po, S. The response of gut associated lymphoid tissues (GALT) flowing oral administration of P. Multocida B2 in rats. Vet On-Line, 2007. Available in: http://www.priory.com/vet/peyers.htm.

Bernsand, M.; Ericsson, P.; Björkqvist, M.; Zhao, C. M.; Hakanson, R. \& Norlen, P. Submucosal microinfusion of endothelin and adreline mobilizes ECL-cell histamine in rat stomach and causes mucosal damage: a microdialysis study. Br. J. Pharmacol.,140(4):707-17, 2003.

Briguet, A.; Courdier-Fruh, I.; Foster, M.; Meier, T. \& Magyar, J. P. Histological parameters for the quantitative assessment of muscular dystrophy in the mdx-mouse. Neuromuscul. Disord., 14(10):675-82, 2004.

Burkitt, M. D.; Varro, A. \& Pritchard, D. M. Importance of gastrin in the pathogenesis and treatment of gastric tumours. World $J$. Gastroenterol., 15(1):1-16, 2009. 
Crompton, G. A brief history of inhaled asthma therapy over the last fifty years. Prim. Care Respir. J., 15(6):326-31, 2006.

D’Ambrosio, D.; Panina-Bordignon, P. \& Sinigaglia, F. Chemokine receptors in inflammation: an overview. J. Immunol. Methods, 273(1-2):3-13, 2003

Fahy, J. V. Goblet cell and mucin gene abnormalities in asthma. Chest, 122(6):320S-6S, 2002.

Garrod, O. The pharmacology of cortisone, cortisol (hydrocortisone) and their new analogues. Postgrad. Med.J., 34(392):300-4, 1958.

Gordon, B. R. Asthma history and presentation. Otolaryngol. Clin. North Am., 41(2):375-85, vii-viii, 2008.

Gwinn, W. M.; Damsker, J. M.; Falahati, R.; Okwumabua, I;, KellyWelch, A.; Keegan, A. D.; Vanpouille, C.; Lee, J. J.; Dent, L. A.; Leitenberg, D.; Bukrinsky, M. I. \& Constant, S. L. Novel approach to inhibit asthma-mediated lung inflammation using anti-CD147 intervention. J. Immunol., 177(7):4870-9, 2006.

Holgate, S. T. Pathogenesis of Asthma. Clin. Exp. Allergy, 38(6):87297, 2008.

Kay, A. B. Leukocytes in asthma. Immunol. Invest., 17(8-9):679$705,1988$.

Kelly, M.; Hwang, J. M. \& Kubes, P. Modulating leukocyte recruitment in inflammation. J. Allergy Clin. Immunol., 120(1):3$10,2007$.

Lopez-Diaz, L.; Hinkle, K. L.; Jain, R. N.; Zavros, Y.; Brunkan, C. S.; Keeley, T.; Eaton, K. A.; Merchant, J. L.; Chew, C. S. \& Samuelson, L. C. Parietal cell hyperstimulation and autoimmune gastritis in cholera toxin transgenic mice. Am. J. Physiol. Gastrointest. Liver Physiol., 290(5):G970-9, 2006.

Lloyd, C. M. \& Rankin, S. M. Chemokines in allergic airway disease. Curr. Opin. Pharmacol., 3(4):443-8, 2003.

Mauad, T.; Bel, E. H. \& Sterk, P. J. Asthma therapy and airway remodeling. J. Allergy Clin. Immunol., 120(5):997-1009, 2007.

Modul8 Inc. Modul8 - increase your immunity naturally, 2009. Available in: http://www.modul8sa.co.za/index.php.

Nakajima, T.; Konda, Y.; Izumi, Y.; Kanai, M.; Takeuchi, T. \& Chiba, T. Gastrin interfers with the differentiation of gastric pit cells and parietal cells. Aliment. Pharmacol. Ther, 16(Suppl. 2):3-9, 2002.

Nauta, A. J.; Engels, F.; Knippels, L. M.; Garssen, J.; Nijkamp, F. P.; \& Redegeld, F. A. Mechanism of allergy and asthma. Eur. J. Pharmacol., 585(2-3):354-60, 2008.

Nelson, D. L. \& Cox, M. M. Lehninger, Principles of Biochemistry. $4^{\text {th }}$ edn. New York, W. H. Freeman and Company, 2005.
Nepomnyashchikh, G. I.; Chernyavskaya, G. M.; Aidagulova, S. V. \& Korabel'nikov, D. I. Ultrastructural Changes in Cells of the Gastric and Small Intestinal Mucosa during Bronchial Asthma. Bull. Exp. Bio. Med., 137(3):341-6, 2004.

Rang, H. P.; Dale, M. M.; Ritter, J. M. \& Moore, P. K. Pharmacology. $5^{\text {th }}$ edn. Edinburgh, Churchill Livingstone, 2003.

Rogers, D. F. Airway goblet cell hyperplasia in asthma: Hypersecretory and anti-inflammatory? Clin. Exp. Allergy, 32(8):1124-7, 2002.

Rudzik, R.; Clancy, R. L.; Perey, D. Y.; Day, R. P. \& Bienenstock, J. Repopulation with IgA-containing cells of bronchial and intestinal lamina propria after transfer of homologous Peyer's patch and bronchial lymphocytes. J. Immunol., 114(5):1599-604, 1975.

Sumi, Y. \& Hamid, Q. Airway remodeling in asthma. Allergol. Int., 56(4):341-8, 2007.

Tani, S.; Tanaka, T.; Kudo, Y. \& Takahagi, M. Pepsinogen secretion from cultured rat gastric mucosal cells. Chem. Pharm. Bull., 37(8):2188-90, 1989.

Tani, S. \& Tanaka, T. Direct inhibition of pepsingogen secretion from rat gastric chief cells by somatostatin. Chem. Pharm. Bull., 38(8):2246-8, 1990.

Venge, P. Eosinophil. In: Barnes, P. J.; Rodger, I. W. \& Thomson, N. C. (Eds.) Asthma: basic mechanisms and clinical management. $3^{\text {rd }}$ edn. San Diego, Academic Press, 1988. pp.141-57.

Wallaert, B.; Desreumaux, P.; Copin, M. C.; Tillie, I.; Benard, A.; Colombel, J. F.; Gosselin, B.; Tonnel, A. B. \& Janin, A. Immunoreactivity for interleukin 3 and 5 and granulocyte/ macrophage colony-stimulating factor of intestinal mucosa in bronchial asthma. J. Exp. Med., 182(6):1897-904, 1995.

Warner, S. M. \& Knight, D. A. Airway modeling and remodeling in the pathogenesis of asthma. Curr. Opin. Allergy Clin. Immunol., 8(1):44-8, 2008.

Wiederanders, R. E.; Classen, K. L.; Gobbel, W. G. Jr. \& Doyle, M. $\mathrm{M}$. The effect of cortisone acetate on gastric secretion. Ann. Surg., 152:119-28, 1960.

\section{Correspondence to:}

Etheresia Pretorius

Department of Physiology

Faculty of Health Sciences

University of Pretoria

Private Bag x323

0007, Arcadai

SOUTH AFRICA

Email: resia.pretorius@up.ac.za

Received: 15-07-2011

Accepted: 05-09-2011 